\title{
0 futebol no âmbito mais geral do jogo
}

\author{
Football in the most General Context of Play
}

\author{
Pedro Lerner Garcia \\ Universidade de São Paulo, São Paulo, Brasil \\ Doutorando em Teoria Literária e Literatura Comparada, USP \\ pedrolerner@gmail.com
}

REsumo: A reunião das ideias apresentadas neste artigo busca situar o futebol na perspectiva mais geral do jogo humano, aproximando autores de campos diversos, que vão da filosofia à crítica literária, para entender o que faz do futebol o mais popular entre os esportes globalizados. 0 jogo como símbolo do mundo e como origem da cultura, os tipos de jogo segundo os diferentes princípios que os regem, o papel do acaso no futebol, as diferentes maneiras de se assistir a uma partida e as semelhanças entre a experiência estética do futebol e a do teatro são alguns dos temas pelos quais este artigo passará.

Palavras-chave: Futebol; Jogo; Acaso; Espectador.

ABTRACT: The gathering of ideas presented in this article seeks to place football in the most general perspective of human game, bringing together authors from different fields, ranging from philosophy to literary criticism, to understand what makes football the most popular among globalized sports. Play as a symbol of the world, as the origin of culture, the types of game according to the different principles that govern them, the role of chance in football, the different ways of watching a match and the similarities between aesthetic experiences of football and theater are some of the themes that this article will cover.

KEYWORDS: Football; Game; Chance; Viewer. 


\section{JOGO E CULTURA}

Johan Huizinga afirma que "a civilização humana não acrescenta característica essencial alguma à ideia geral de jogo". ${ }^{1}$ A própria civilização ou cultura aparece emergindo a partir do princípio do jogo, cuja presença está na origem de elementos arquetípicos da sociedade humana como o mito, o culto e a própria linguagem: comunicar-se é jogar. $^{2} 0$ jogo é por definição uma atividade voluntária, e esse elemento constitutivo de liberdade basta para afastá-lo definitivamente do âmbito da seleção natural; ele é uma espécie de semente civilizatória que recobre a evolução como um ornamento ou uma roupagem. Em qualquer momento é possível suspender ou adiar o jogo, que nunca é uma necessidade física ou um dever moral, o que leva Huizinga a concluir que o jogo é fundamentalmente livre ou, ainda, é ele próprio liberdade. Ademais não é vida corrente nem vida real, o que o torna desinteressado, exterior ao circuito de satisfação imediata de necessidades e desejos da vida comum.

A terceira característica fundamental do jogo, depois da liberdade e do desinteresse, é um isolamento, já que ele é jogado do início ao fim dentro de certos limites de tempo e espaço. 0 jogo instaura mundos temporários dentro do mundo habitual e estabelece um ritmo feito de alternâncias e repetições, criando em seu domínio uma ordem específica e absoluta. Essa é mais uma característica inegociável do jogo: ele cria e é ordem. A tensão que instaura, por sua vez, lhe confere um valor ético na medida em que coloca à prova não só as qualidades do jogador, tais como força, tenacidade, habilidade e coragem, mas também um sentido de lealdade, uma vez que o jogador, por muito que queira ganhar, deve sempre obedecer às regras do jogo. $\mathrm{A}$ desobediência põe fim ao mundo do jogo, trazendo os jogadores de volta ao âmbito da vida real. É por isso que o trapaceiro, aquele que infringe as regras por trás dos panos, é mais facilmente tolerado do que o estraga-prazeres, inimigo do jogo por denunciar o absurdo de sua ficção.

\footnotetext{
${ }^{1}$ HUIZINGA. Homo ludens, p. 3.

${ }^{2}$ Como em Freud, que escreve na mesma época, não há distinção entre cultura e civilização em Huizinga.
} 
O jogo não é somente anterior à civilização, mas também superior ou ao menos autônomo em relação a ela. ${ }^{3}$ A cultura surge sob a forma do jogo e é, em seus primeiros passos, "jogada", mas isso não quer dizer que o jogo se transforma em cultura "e sim que em suas fases mais primitivas a cultura possui um caráter lúdico, que ela se processa segundo as formas e no ambiente do jogo". ${ }^{4}$ Com a complexificação das sociedades humanas, no entanto, o elemento lúdico vai recuando aos poucos para o segundo plano, sendo absorvido pela esfera do sagrado ou cristalizando-se em formas de saber como o folclore, a filosofia, o direito ou a política.

0 parentesco entre jogo e direito, por exemplo, se evidencia no caráter agonístico do processo judiciário. Quem diz competição, afirma Huizinga, diz jogo, e o lúdico e o competitivo permanecem presentes em todas as esferas da vida jurídica. A afinidade começa pelo tribunal, que assim como o campo de jogo é um lugar sagrado, separado e afastado do mundo vulgar, passa pelo desejo intenso de ganhar, nutrido por ambas as partes em qualquer processo submetido a um juiz, e chega por fim às batalhas verbais dos advogados, cuja dimensão performática e agonística é evidente. 0 que Huizinga destaca, no entanto, é que a justiça primitiva não fazia distinção entre as ideias de sorte, mérito e vontade divina. A balança da justiça, metáfora que surge de uma imagem homérica, é a mesma da perpétua oscilação da sorte, e qualquer ideia de triunfo da verdade, da moral ou de um bem que pese mais do que um mal só viria a surgir muito mais tarde:

Zeus segura os divinos decretos do destino e da justiça em uma mesma balança. Os Ases jogam aos dados o destino do mundo. 0 espírito primitivo não distingue, como manifestações da Vontade Divina, entre o resultado de uma prova de força, ou o de uma luta armada, e a maneira como cai um punhado de pedras ou de pauzinhos. (...) Para o espírito primitivo o fato de ganhar, enquanto tal, é prova da posse da verdade e do direito; o resultado de qualquer competição, seja uma prova de força ou um jogo de sorte, é uma decisão sagrada, concedida pelos deuses. ${ }^{5}$

\footnotetext{
3 HUIZINGA. Homo ludens, p. 23.

${ }^{4}$ HUIZINGA. Homo ludens, p. 53.

${ }^{5}$ HUIZINGA. Homo ludens, p. 92 ..
} 


\section{O JOGO DO MUNDO}

0 argumento da primazia do jogo é colocado de maneira ainda mais radical por Eugen Fink, para quem o jogo desvela um caminho filosófico para a compreensão da existência. Deslocado da periferia da vida para o centro do cosmos, o jogo aparece como a atividade capaz de transcender a finitude humana e oferecer a linguagem mais adequada para abordar o todo do mundo. 0 jogo cósmico de Fink é, em suma, “um símbolo especulativo para 'interpretar' o movimento global da realidade do mundo por analogia com o jogo humano", 6 e seu projeto é investigar a relação de uma coisa intramundana particular, o homem, com a totalidade do mundo. 0 estudo do jogo tem como objetivo chegar a uma concepção original das diferenças e afinidades entre o homem e o cosmos ou, em outras palavras, a uma nova teoria acerca do lugar do homem no mundo.

Fink acredita que o destino de nossa razão humana é ser atraída e instigada pelo pensamento da totalidade, o que explicaria nosso "sentimento de imensa nostalgia do ilimitado, um sentimento oceânico que nos assola quando lançamos nossos olhares sobre 'vastos oceanos' ou contemplamos o 'céu estrelado' acima de nós".7 Ele resgata um fragmento de Heráclito no qual a ordem do mundo é definida como um fogo eternamente vivo, infere daí que homens e deuses seriam os únicos seres determinados por sua relação com esse fogo criador e afirma, em seguida, que o fogo cósmico de Heráclito é, também, o próprio tempo do mundo com suas dimensões de passado, presente e futuro. ${ }^{8}$ É por isso que a Fink parece tão decisivo que Heráclito escreva, em outro fragmento, que o tempo do mundo é uma criança que joga. 0 mundo reina como jogo, e é através do jogo que deuses e homens travam uma relação aberta com o fogo criador.

\footnotetext{
${ }^{6}$ FINK. Le jeu comme symbole du monde, p. 17. No original: "un symbole spéculatif pour 'interpréter' le mouvement global de la réalité du monde par analogie avec le jeu humain". Todas as traduções são de minha autoria.

${ }^{7}$ FINK. Le jeu comme symbole du monde, p. 24. No original: "sentiment d'immense nostalgie de l'illimité, un sentiment océanique que nous éprouvons lorsque nous lançons nos regards sur de 'vastes océans' ou que nous contemplons le 'ciel étoilé' au dessus de nous".

8 FINK. Le jeu comme symbole du monde, p. 28.
} 
A conclusão de Fink é que o jogo humano é o modo privilegiado pelo qual a existência se deixa atravessar e animar pelo todo. 0 jogo aparece, ainda, como uma curiosa espécie de liberdade: se o homem, em suas decisões livres, determina sua individualidade e constrói para si uma realidade particular entre as múltiplas possibilidades abertas, se tornando cada vez mais o resultado de suas escolhas, o jogo o liberta temporariamente da historicidade de suas ações e do legado de sua liberdade, proporcionando uma irresponsabilidade que vivemos com prazer. Nessa espécie de abertura ilimitada o homem se perde na ação e pode experimentar o que há de lúdico no fundo da liberdade, o que há de irresponsável na origem de toda responsabilidade. Toca, assim, o que há de mais profundamente ligado ao mundo dentro de si, e uma das belezas da formulação de Fink é que o jogo, através de um tipo peculiar de irrealidade, figura como aquilo que liberta o homem de sua própria liberdade. ${ }^{9}$

O jogo aparece como símbolo do mundo na medida em que ambos, e só eles, parecem escapar ao esquema da causalidade. 0 jogo humano, em meio à causalidade geral das coisas intramundanas, é o lugar onde surge um elã da vida se movendo sem razão própria como símbolo do governo do mundo. 0 mundo é um jogo sem jogador, ao mesmo tempo em que todo jogador é também jogado. "É porque nós somos abertos ao mundo e porque essa abertura da existência humana ao mundo implica que o homem saiba que o todo que age é sem razão, é por isso que nós somos capazes de jogar". 10

\section{TIPOS DE JOGO}

Roger Caillois lembra que a palavra jogo designa não somente a duração do ato de jogar, mas também o conjunto dos elementos necessários para a realização do ato. Assim, fala-se em jogo de cartas para designar o baralho ou jogo de xadrez referindose ao tabuleiro e às peças necessárias para disputar uma partida. Nesses casos,

\footnotetext{
${ }^{9}$ FINK. Le jeu comme symbole du monde, p. 229.

${ }^{10}$ FINK. Le jeu comme symbole du monde, p. 236. No original: "C'est parce que nous sommes ouverts au monde et que cette ouverture de l'existence humaine au monde implique que l'homme sait que le tout agissant est sans raison, c'est pour cela que nous sommes capables de jouer".
} 
assim como no futebol e demais esportes coletivos, é necessária a presença de todos os elementos sob pena de o jogo ser inviabilizado ou viciado desde o princípio. Usarse-á também a palavra jogo quando se trate de assuntos que não envolvam disputa, como em jogo de pratos ou de lençóis. Essa referência a uma totalidade que se supõe suficiente deixa entrever o sentido de jogo como algo delimitado em relação a um ambiente externo, uma espécie de espaço de exceção que supõe regras e dinâmicas próprias. Jogo é, ainda, a margem de manobra de determinadas engrenagens, como quando falamos que um carro tem bom jogo, significando que suas rodas giram bastante em torno de seu próprio eixo e dessa forma permitem que o carro faça curvas com facilidade. Jogo é também, portanto, a liberdade que permanece no próprio rigor para que esse alcance sua eficácia.

$\mathrm{O}$ outro conceito que o jogo traz à tona de imediato é o de risco. 0 jogador está sempre na posição de avaliar os recursos disponíveis e, a partir deles, decidir o quanto vale a pena arriscar em nome de seus objetivos. Esse modelo vale desde os jogos de carta, onde o jogador conhece sua mão e pode decidir por sair da rodada ou seguir apostando - no caso de ter um jogo ruim, pode optar por blefar e confiar não na qualidade das suas cartas, mas na sua capacidade de dissimulação -, até os mais complexos esportes de equipe: no futebol, por exemplo, cabe ao time e ao técnico avaliarem atributos como qualidade técnica e velocidade de ambas as equipes para decidirem o quanto estão dispostos a atacar tendo em vista os espaços que um posicionamento ofensivo pode oferecer para contra-ataques. 0 blefe, por sua vez, aparece em equipes que se encolhem na defesa durante partidas inteiras, afastando a bola com chutões e fingindo-se incapazes de atacar, apenas para em um lance, quando o adversário se julga invulnerável, marcar o gol da vitória em um contraataque perfeitamente articulado.

Os jogos regulamentados são divididos por Caillois em duas categorias: jogos de competição (agôn), em que a igualdade de oportunidades é criada artificialmente para que os adversários se enfrentem em condições ideais; e jogos de azar (alea), nos quais o resultado não depende das decisões do jogador e se trata muito mais de vencer o destino do que um adversário. Enquanto nos jogos de competição, sejam eles de força física, como o atletismo, ou de aptidão mental, como o xadrez, a vitória se dá por mérito e torna supostamente indiscutível a superioridade do vencedor, 
nos jogos de azar (como a roleta, os dados ou mesmo o cara ou coroa) o vencedor é simplesmente aquele que foi mais contemplado pela sorte. Aqui não se busca eliminar a injustiça do acaso; celebra-se, ao contrário, sua arbitrariedade. Enquanto o agôn afirma a responsabilidade individual, a alea celebra a entrega ao destino. Nas quatro categorias de jogo que reconhece, já que além dos já citados há ainda os de imitação (mimicry) e os de vertigem (ilinx), Caillois vê combinações possíveis, proibidas e fundamentais. A sorte (alea) pode combinar-se com a vertigem (ilinx) e a competição (agôn) pode combinar-se com a simulação (mimicry), mas as combinações essenciais e mais frequentes se dariam entre mimicrye ilinx, de um lado, e de outro entre agôn e alea, que apresentam em comum a busca de um modelo ideal que garanta aos jogadores as mesmas possibilidades de triunfo e fracasso.

\section{COMPETÊNCIA E SORTE}

Jogos acentuam as preferências e refletem as crenças das culturas nas quais se situam. Caillois acredita numa solidariedade entre toda e qualquer sociedade e os jogos que nela predominam, de forma que os jogos manifestam e sancionam tendências, gostos e formas de pensar. Que um povo prefira um jogo em detrimento de outros poderia, portanto, servir como dado para delinear seus traços morais e intelectuais. Não seria nem mesmo absurdo, para Caillois, esboçar o diagnóstico de uma civilização a partir dos jogos que nela prosperam. Sociedades e culturas atribuem diferentes valores à competição, à sorte, à mímica e ao transe, e os princípios do jogo (agôn, alea, mimicry, ilinx), motores universais da atividade humana, estão sempre presentes organizando o tecido das relações sociais. Caillois postula a ideia de que as sociedades primitivas se organizavam em torno da mimicry e do ilinx, enquanto a passagem à civilização consistirá na sua substituição, enquanto cerne das relações sociais, pela dupla agôn-alea. As pulsões de simulacro e de vertigem, então, serão empurradas para a periferia da vida.

$\mathrm{Na}$ Grécia, quando o reinado da máscara (e da mimicry e do ilinx) já caminha para se tornar o da impostura e da charlatanice, os grandes jogos e o próprio processo político já denotam a primazia do par agôn-alea na vida social. A competição aparece na base da vida institucional através de provas e concursos, mas os postos 
mais altos ainda são privilégio das castas dominantes ou, em outras palavras, continuam definidos não pelo mérito, mas pelo acaso do nascimento. Por mais que as sociedades modernas tendam, através de suas instituições e competições regulamentadas, a alargar o domínio do mérito em detrimento do da herança, o acaso do nascimento continua a desempenhar um papel fundamental e só existirá uma concorrência efetiva entre pessoas do mesmo estrato, da mesma origem e do mesmo meio. 0 indivíduo de classe pobre, portanto, normalmente percebe em algum momento que sua sorte está lançada e que a dedicação e o mérito, embora possam mitigar sua condição, jamais serão suficientes para uma mudança radical de vida. Há também, no outro extremo, aqueles que se dão conta de não ter muito a esperar do próprio mérito. Aqui reside, então, a importância das loterias e demais concursos de sorte, espécie de remissão compensatória da alea no seio do agôn.

Tanto a sorte quanto o mérito, no entanto, contemplam apenas alguns eleitos no que concerne ao direito de ser o primeiro, o melhor ou ao menos destacar-se e alcançar fama e reconhecimento. Caillois aponta então para o que chama de triunfo por delegação, espécie de retorno da mimicry em sua única forma capaz de prosperar em um mundo regido pelo agôn e pela alea. 0 triunfo por delegação, que consiste em vencer por intermédio de outrem, estaria no cerne do culto às celebridades: "A vedeta e o campeão propõem imagens deslumbrantes dos únicos sucessos grandiosos que podem caber, com a ajuda da sorte, ao mais anônimo e ao mais pobre".11

\section{O FUTEBOL}

Caillois cita o dominó, o gamão e a maioria dos jogos de cartas como exemplos de jogos em que agôn e alea se combinam. É compreensível que, dentro dos limites dessas categorias, ele situe os esportes de equipe no âmbito dos jogos de competição. A crônica futebolística, no entanto, destaca repetidamente o papel do acaso no futebol (ou, no jargão mais típico, o papel da sorte, do azar ou da falta de sorte), influência essa que se mostrará especialmente decisiva mesmo na comparação com outros esportes de equipe complexos como o basquete, o vôlei, o futebol americano

${ }^{11}$ CAILLOIS. Os jogos e os homens, p. 144. 
ou o beisebol. Essa abertura do futebol à contingência se deve às suas próprias regras, que impedem os jogadores de usar as mãos, tornam a pontuação um evento mais raro do que em quase qualquer outro esporte e deixam, mesmo após o advento do árbitro de vídeo (VAR), uma grande gama de situações a serem definidas pela interpretação subjetiva do árbitro.

José Miguel Wisnik associa o surgimento do futebol à relação particular entre campo e cidade que é própria da experiência inglesa. Coloca-o, assim, em oposição a esportes posteriores e marcadamente citadinos que se caracterizam pela alternância serializada da posse da bola, como o vôlei e o basquete, disputados em arenas cobertas, sobre terrenos pavimentados e na maioria das vezes a uma velocidade vertiginosa. Ao discorrer sobre as afinidades do futebol com o mundo agropecuário, que vão desde a exposição às intempéries da natureza até os atemporais "montinhos artilheiros", passando pelos lamaçais e poças nos quais chafurdam ataques e defesas, Wisnik acaba tecendo um comentário sobre o papel marcante que, no futebol mais do que nos outros esportes, é desempenhado por tudo aquilo que foge ao controle dos jogadores:

Desenvolvendo uma linguagem dos pés, do hemisfério corporal menos especificado e, em princípio, cego para os controles sutis e a precisão objetiva mais acurada, e reduzindo as mãos à intervenção de última instância, possível só ao goleiro, o futebol reverte o hábito corporal e instaura uma espécie de "mundo às avessas" em que a posse de bola é muito mais frágil e transitória do que nos esportes manuais. 0 que contribui para a amplitude possível da sua gama de acontecimentos: a extensão do campo cheio de surpresas em que a bola, para percorrer a distância entre um gol e outro, tem de fazer uma verdadeira viagem, sujeita a toda sorte de peripécias, idas e vindas, marchas e contramarchas, cheia de alternâncias e lembrando mais os movimentos no meio rural do que os ritmos diretos dos choques no meio urbano. ${ }^{12}$

Wisnik vai mais longe e afirma que, se por um lado a ênfase crescente dos treinadores de futebol na posse de bola tem como objetivo último uma espécie de neutralização do acaso, por outro lado o nivelamento trazido pela evolução física e tática do esporte faz com que o mantra segundo o qual o "jogo será definido no detalhe", tão repetido por técnicos e jogadores, seja uma espécie de eufemismo para o fato de que, numa situação de equilíbrio absoluto, a vitória e a derrota acabam por

\footnotetext{
12 WISNIK. Veneno remédio, p. 98.
} 
ser definidas mais que tudo pelo acaso. Somando-se ao acaso imponderável do espaço e do tempo, por um lado, e a uma espécie de acaso subjetivo que se manifesta na genialidade do craque, por outro, aparece por fim uma espécie de acaso da interpretação cujo personagem propulsor é o árbitro. Nenhum outro jogo arbitrado, argumenta Wisnik, é tão sujeito à interpretação quanto o futebol, que coloca de forma única o problema insuperável da intenção. Mão na bola ou bola na mão? Maldade, imprudência ou mera falta de sorte? Cartão amarelo ou vermelho? 0 juiz é "um hermeneuta que deve dirimir judiciosamente, em tempo real, a nebulosa questão da intencionalidade (houve ou não houve, não propriamente o fato objetivo, mas a sombra quase religiosa de uma culpa?)". ${ }^{13}$

No basquete, no vôlei e nos outros esportes, por outro lado, não parece nunca se tratar de saber se houve ou não intenção, e sim de legislar sobre questões objetivas como se a bola caiu dentro ou fora da quadra, tocou ou não na linha ou no bloqueio, o jogador resvalou ou não na rede. Nunca haverá, no basquete, a discussão sobre se a bola entrou ou não na cesta, enquanto no futebol a questão é muitas vezes indecifrável mesmo com a ajuda de dezenas de câmeras posicionadas em diferentes ângulos. No futebol, ao contrário do que já acontecia em todos os outros esportes, ao árbitro não era dada, quando Wisnik escrevia, a possibilidade de rever o lance que suscitara a dúvida. Só existia o tempo presente, e era nele que o árbitro devia agir, ficando assim tantas vezes ao acaso a decisão sobre se veria um puxão de camisa, uma bola na mão ou uma agressão ou se, justo naquele momento, sua visão estaria bloqueada por um atleta que passava entre ele e a jogada num deslocamento imprevisto. Foi Gilberto Gil quem afirmou, em transmissão da Rede Globo, que as infrações no futebol não existem objetivamente, seja na realidade ou na câmera, mas somente na diminuta fração de tempo em que podem ser captadas pelo árbitro durante o jogo. É possível argumentar, nesse sentido, e mantendo-se afastado da discussão sobre se o VAR ajuda ou não a minimizar erros de arbitragem, que o próprio recurso ao árbitro de vídeo corrompe de forma grave uma característica importante do futebol.

${ }^{13}$ WISNIK. Veneno remédio, p. 107. 


\section{ACASO E DESTINO}

Caillois afirma que em ambas as combinações essenciais (agôn-alea, mimicry-ilinx) parece estar em cena um elemento ativo e fecundo, ligado à vontade e à aplicação, e um outro passivo e pernicioso, ligado a entrega e aceitação. É assim que o agôn, desejo de vitória e crença no esforço, carrega a fertilidade da ambição na medida em que o indivíduo confia em seus próprios recursos para vencer e dar prova de sua excelência, enquanto a alea surge como uma aceitação prévia e incondicional do destino. Um indício adicional do pertencimento do futebol também à alea, nesse sentido, é a frequência de menções ao acaso e a forças incontroláveis no discurso de perdedores e vencedores, presente em jargões como "quem não faz, leva" ou "a bola não quis entrar”. É quase inexistente, em outros esportes, a menção ao acaso na explicação de vitórias e derrotas.

Nuno Ramos faz um inventário, em ensaio sobre os aspectos trágicos do futebol que chama de Os suplicantes e dedica a José Miguel Wisnik, de tudo aquilo que no futebol é decidido pela sorte na forma de detalhes imponderáveis e fugidios. 0 futebol tende a criar uma confiança excessiva após a vitória e um discurso catastrófico após a derrota quando, na verdade, é na maioria das vezes por tão pouco que se ganha ou se perde:

A ponta dos dedos do goleiro, vinte centímetros de avanço do atacante na hora do lançamento, a visão encoberta do juiz no lance do pênalti ou até mesmo uma reação imprevista de um jogador, como uma cabeçada no peito do adversário, numa final de Copa do Mundo, a doze minutos do fim de uma carreira gloriosa. 0 apito final estabiliza violentamente aquilo que, no transcorrer do jogo, parece um rio catastrófico de mil possibilidades, a nos arrastar com ele. (...) Nenhum outro esporte coletivo possui tamanha ausência de sintonia entre o que se passa em campo e o resultado. Torcer, experimentar sem reservas um jogo de futebol, é aproximar-se dessa separação entre jogo e placar. Pode-se dizer que todo jogo de futebol que mereça ser lembrado é no limite um jogo injusto, um jogo que o placar não consegue sintetizar nem estabilizar a posteriori. Creio que nenhum outro esporte coletivo possui, em sua medula, esta característica. ${ }^{14}$

\footnotetext{
${ }^{14}$ RAMOS. Ensaio geral, p. 245.
} 
Subsiste, dentro do jogo, um outro jogo funcionando quase como a contrapelo do placar e da realidade que se consuma. A pergunta $e$ se, tão estúpida quanto inevitável, figura então para Nuno Ramos como uma espécie de núcleo profundo e incontrolável do futebol. É como se esse esporte, em sua abertura contínua e constitutiva ao acaso, fosse feito de bifurcações infinitas que o transformam numa espécie de narrativa não tão diferente do teatro, da literatura ou do jogo ideal nietzscheano onde não existem vencedores e vencidos. Isso se deve, segundo Ramos, a duas características básicas: a dificuldade do ponto e o número enorme de possibilidades produzidas pelo jogo.

Essa gama de possibilidades está associada acima de tudo à alternância constante da posse de bola, que, em função da proibição de reter a pelota com as mãos, continua a diferenciar o futebol a despeito do foco atual na posse de bola como estratégia para diminuir o risco inerente ao fluxo das jogadas. A dificuldade de se pontuar, por sua vez, se dá em razão de o campo ser enorme, de jogar-se com os pés e a cabeça, incapazes de reter a bola, e de o goleiro, ao contrário dos demais jogadores, poder usar as mãos. Essa dificuldade acaba criando uma espécie de inércia que promove uma aproximação entre jogo e vida. As regras são extremamente simples se comparadas às dos outros esportes, o tempo do jogo é o mesmo do relógio (ao contrário do basquete e do futebol americano, por exemplo, que interrompem o cronômetro a todo instante) e o campo é grande o suficiente para manter zonas de dispersão. A cal deixa sua marca no corpo dos jogadores, as chuteiras tiram nacos da grama e a chuva, se cai, é a mesma que banha a cidade. “O jogo, um pouco como o mar, está rugindo à nossa frente - uma vez posto em movimento, não deve ser interrompido. Muitos de seus aspectos propriamente trágicos vêm desta literalidade de tempo e espaço, dessa contiguidade com a vida".15

O gol, por sua vez, aparece como um rompimento, já que não é o resultado acumulado das jogadas anteriores mas decorre, na verdade, apenas das circunstâncias que levam imediatamente a ele, circunstâncias essas que sempre dão a impressão retrospectiva de poderem ter sido evitadas. Há sempre um hiato ou um degrau entre o jogo e o gol, e isso está para Ramos na origem do que parece único no futebol:

${ }^{15}$ RAMOS. Ensaio geral, p. 248. 
Se o possível do jogo surge como inesgotável é porque nunca se cumpre verdadeiramente, já que não altera com a frequência necessária a fixidez do placar; isto é tão intenso que quando o gol sai afinal também ele parece uma circunstância, não uma necessidade. (...) 0 jogo carrega uma ferida interna insaciável, que apenas as partidas com enorme disparidade entre os dois times conseguem aquietar, pois toda a promessa das jogadas, das bolas na trave, das chances desperdiçadas, dos pênaltis inexistentes ou não marcados, vem cobrar a sua vez, como uma alma penada à espera de justiça. ${ }^{16}$

Wisnik cita Ramos e escreve que "o apito final, como a morte, sela o sentido do acontecimento, mas sem sossegar necessariamente as virtualidades que o jogo desencadeia, as promessas que ele quase realizou, a multidão de alternativas que ele desenha". ${ }^{17}$ É por isso que para Ramos, se é típico do empate uma discussão interminável a respeito de quem jogou melhor e portanto merecia vencer, os jogos com vencedores costumam deixar herdeiros do placar, os vitoriosos, e herdeiros das jogadas, os perdedores, órfãos de erros do juiz e chances perdidas para quem o sentido trágico do futebol adquire toda a sua dimensão. A esses parecerá sempre que poderia ter sido diferente, e o resultado se apresentará como obra do acaso e nunca necessidade.

Mas a sobrevivência e a vitória do placar, que permanecerá enquanto o resto terminará esquecido, faz pensar também em uma espécie de destino, imperceptível no decorrer da partida, quando o resultado parece ainda depender dos jogadores e da sorte, mas revelado retrospectivamente pelo apito e o resultado final. 0 trágico emerge de um possível que se anunciou e não se concretizou, e Ramos termina seu ensaio perguntando se o que o futebol teria de mais potente e secreto, e que apareceria com força sobretudo nas derrotas, não seria "o fato de que não pertence inteiramente aos jogadores? 0 fato de que, como verdadeiros heróis trágicos, algo que nunca controlam, mas de que participam intensamente, se faz através e apesar deles?".18

\section{FUTEBOL E VIDA}

Roberto DaMatta, que chegou a conclusões tão interessantes quanto questionáveis acerca do lugar do futebol no Brasil, é outro a explicitar uma certa tensão entre as ideias de acaso e destino no seio da experiência futebolística. Ele afirma que, enquanto nos

\footnotetext{
${ }^{16}$ RAMOS. Ensaio geral, p. 250.

17 WISNIK. Veneno remédio, p. 112.

${ }^{18}$ RAMOS. Ensaio geral, p. 252.
} 
Estados Unidos, na Inglaterra e em outros países o esporte parece estar mais ligado ao controle do físico e à coordenação de indivíduos para dar azo a uma coletividade,

[...] no Brasil o esporte é vivido e concebido comojogo. É uma atividade que requer táticas, força, determinação física e psicológica, habilidade técnica, mas que também depende das forças incontroláveis da sorte e do destino. Realmente, nos comentários após os jogos de futebol, no Brasil, existem muitas situações em que se sabe que um dos times não jogou somente contra o tempo e o adversário, mas também contra o destino, que deve ser modificado ou corrigido para que a vitória possa lhe sorrir.19

DaMatta prossegue afirmando que, se no universo individualista dos países anglo-saxãos o futebol pode perfeitamente funcionar como um mecanismo de coletivização, criando a camaradagem e o fair-play, no Brasil ele tende a valorizar a improvisação e a individualidade dos jogadores, se convertendo numa fonte de singularização e possibilidade de expressão individual muito mais do que num instrumento em prol da coletividade. A dramatização operada pelo futebol, para o autor, seria uma que opõe o destino impessoal das equipes a uma vontade individual que, no caso brasileiro, busca escapar ao ciclo da derrota e da pobreza. Do embate entre regras universais, as regras do jogo, e vontades individuais, as dos jogadores em confronto, surge uma imagem do jogo como destino e biografia. 0 fascínio do futebol estaria, então, nas interações complexas (de um time com o outro, entre os jogadores de um mesmo time, das equipes com as regras e com o público) que permitem interpretar o jogo de futebol como uma metáfora da própria vida. Mas se a aproximação entre futebol e vida empreendida por Wisnik e Ramos se referia, acima de tudo, a uma abertura ao acaso que reduz o peso do mérito a ponto de abolir o placar, a comparação de DaMatta parece, por sua vez, muito mais entre as regras do jogo e a estrutura de uma determinada sociedade. No Brasil, para ele,

[...] a popularidade de esportes como o futebol jaz na capacidade do esporte de possibilitar uma experiência com estruturas permanentes. Com um permanente que se define por meio de regras universais que ninguém pode modificar. Assim, ao contrário da política, onde após cada derrota (ou ao simples vislumbrar da derrota) os grupos dominantes buscam modificar as regras do jogo, o futebol, (esse humilde e aparente instrumento de mistificação das massas), proporciona uma experiência exemplar de legitimidade e acatamento às leis. Aqui as regras não mudam, e isso faz com que todos sejam iguais no campo da disputa. Derrota ou vitória é o

19 DaMATTA e outros, Universo do futebol, p. 25. 
prêmio a ser efetivamente colhido por quem joga melhor. Trata-se, como se observa, da utilização do futebol como um instrumento que permite experimentar a igualdade. Uma forma de igualdade aberta e democrática, pois que inteiramente fundada no desempenho. ${ }^{20}$

Nos termos de Caillois, portanto, DaMatta creditaria o sucesso do futebol no Brasil ao ato de instaurar um mundo regido pelo agôn numa sociedade que, apesar da roupagem democrática, ainda é em grande medida organizada pela alea do nascimento. Embora tenha antes usado termos como sorte e destino para definir a experiência do futebol, aqui DaMatta é bastante claro ao falar numa competição "inteiramente fundada no desempenho" na qual o prêmio é "efetivamente colhido por quem joga melhor".

Caillois mostrou, no entanto, como alea e agôn são complementares e as maneiras pelas quais a alea, através da loteria e outros mecanismos de azar, insiste em penetrar no seio do agôn como uma espécie de compensação. Nenhum regime lúdico pode ser levado às últimas consequências, sob pena da condenação sem arestas de seus desfavorecidos. O agôn precisa da alea para prosperar. Já Nuno Ramos e José Miguel Wisnik mostram, ao escrutinar suas regras e as paixões que desperta, que o acaso está no coração do futebol compreendido como sistema e fenômeno cultural. Esporte de alto rendimento, com suas táticas, treinamentos e consagração ao mérito, mas submetido em larga medida aos desígnios da sorte por conta de peculiaridades em seus próprios limites e forma de disputa. 0 que DaMatta parece deixar escapar é que o futebol se distingue não por erigir um reino do âgon numa sociedade regida pela alea do nascimento, algo que de toda forma não o diferenciaria decisivamente de outros esportes, mas justamente por permitir, esse sim um traço único, o retorno e a afirmação do acaso no cerne de sua mitologia.

Parece mais plausível afirmar que o enorme sucesso do futebol, tanto no Brasil quanto em toda parte, se deve acima de tudo à maneira particular como ele entrelaça competição e sorte em uma narrativa que guarda afinidades fundamentais com a vida nas sociedades modernas. 0 mérito é sim recompensado, mas a desigualdade econômica não deixa jamais de entrar em campo e nunca se está à salvo, à revelia de qualquer noção de justiça, de ser beneficiado ou prejudicado pelo acaso que

${ }^{20}$ DaMATTA e outros, Universo do futebol, p. 39. 
tantas vezes faz lembrar um destino: a bola que não entra por centímetros ou que entra após um desvio imprevisto, o pênalti perdido ou ignorado, a trave que parece se interpor inapelavelmente entre o atacante e o gol. Nas palavras de Tostão, nosso cronista mais propenso a observar com poesia o que o futebol reflete e ensina do mundo, um jogo de futebol "não pode ser visto somente como uma disputa esportiva, de força física, habilidade, criatividade e de técnica individual e coletiva; é também um espetáculo lúdico, teatral e de muita emoção. Todos os sentimentos e contradições humanas estão presentes". ${ }^{21}$

\section{IDENTIFICAÇÃO E APRECIAÇÃo}

Torcedor e espectador são figuras que se confundem, mas não se equivalem. 0 espectador acompanha uma partida pelo interesse que nutre pelo esporte, que pode se dar em função de suas dimensões estéticas, políticas ou dramáticas. 0 torcedor, por sua vez, vai ao estádio ou assiste a um jogo pela televisão acima de tudo pela identificação que sente com um determinado clube ou selecionado nacional, o qual espera que vença a despeito das qualidades táticas ou técnicas que venha a apresentar durante o confronto.

É evidente, porém, que o torcedor é também um espectador mais ou menos sensível à ética e às dimensões estéticas do futebol, de forma que as vitórias alcançadas com excelência futebolística, que tomam a forma de goleadas ou de uma evidente superioridade territorial e simbólica sobre o adversário, são especialmente comemoradas e rememoradas. Sendo o torcedor primordialmente uma figura afetiva, no entanto, cuja essência se encontra em uma identificação e não em uma apreciação, as vitórias mais marcantes e festejadas costumam ser não as incontestáveis, definidas pelo mérito e por uma superioridade evidente, mas as dramáticas e emocionantes, conquistadas com gols nos últimos minutos, de virada ou quando pareciam já impossíveis. 0 torcedor sente as vitórias e derrotas de seu clube como suas, de forma que quanto mais improvável ou heroica, maiores serão a catarse e a alegria. As piores derrotas, da mesma forma, não são as acachapantes e indiscutíveis, mas

${ }^{21}$ TOSTÃO. A perfeição não existe, p. 144. 
as que advém de forma fortuita ou abrupta, causando muitas vezes a sensação de injustiça e de que poderiam não ter acontecido.

O espectador, por outro lado, tem sua experiência caracterizada acima de tudo por uma apreciação, já que não possui uma identificação profunda e definitiva com nenhum dos lados envolvidos na disputa. Senta-se em frente à televisão, ou mesmo vai ao estádio, para se deixar comover, seja pelas glórias, fracassos e redenções de seres humanos; pela habilidade prodigiosa dos maiores craques; pela beleza geométrica das combinações e movimentos; pelo que o jogo oferece em termos de imprevisibilidade e transformação; ou pelo fato de que, nas palavras de Jean-Claude Michéa, "o universo do futebol oferece ainda um certo número de oportunidades para uma visão não capitalista da vida". ${ }^{22}$

Michéa, para quem "o recurso primeiro de um futebol espetacular - portanto ofensivo e coletivamente construído - é o prazer de jogar um pelo outro sobre a base de uma filosofia compartilhada", ${ }^{23}$ também enxerga dois personagens distintos entre os amantes do futebol, aos quais chama de supporters e aficionados. Ainda que se possa aproximar estes últimos do espectador, há a diferença de "que um aficionado é, por definição, não somente um apaixonado, mas também um conhecedor". ${ }^{24} 0$ supporter, por sua vez, interessa ao capitalismo e é equiparável à figura que chamamos de torcedor:

A indústria futebolística pode continuar a recrutar os novos torcedores que ela necessita para garantir suas fatias de mercado - inclusive, portanto, entre os meios intelectuais - enquanto diminuem regularmente, por todos os lados, o número de entusiastas de fato capazes de "ler uma partida" e exercer um olhar crítico sobre a qualidade do jogo oferecido entusiastas que no entanto constituíam, não faz tanto tempo assim, o essencial de um público popular. ${ }^{25}$

\footnotetext{
${ }^{22}$ MICHÉA. Le plus beau but était une passe, p. 52. No original: "I'univers du football offre encore un certain nombre de prises à une vision non capitaliste de la vie". Todas as traduções são de minha autoria.

${ }^{23}$ MICHÉA. Le plus beau but était une passe, p. 53. No original: "le ressort premier d'un football spectaculaire - donc offensif et collectivement construit - c'est le plaisir de jouer l'un pour l'autre sur la base d'une philosophie partagée".

${ }^{24} \mathrm{MICHÉA}$. Le plus beau but était une passe, p. 128. No original: "qu'un aficionado est, par définition, non seulement un passionné, mais également un connaisseur".

${ }^{25}$ MICHÉA. Le plus beau but était une passe, p. 24. No original: L'industrie footballistique peut continuer de recruter les nouveaux supporters dont elle a besoin pour accroître ses parts de marché - y compris, par conséquent, dans les milieux intelectuels - tout en diminuant régulièrement, par ailleurs, le nombre d'amateurs avertis capables de 'lire un match' et d'exercer un regard critique sur la qualité du jeu offert - amateurs que constituaient pourtant, il n'y a pas si longtemps encore, l'essentiel d'un public populaire".
} 
Conhecedor ou não, de toda forma, o entusiasta a quem chamamos de espectador pode apreciar a excelência tática e estética, a precisão da técnica ou a beleza do estilo, mas assiste às partidas de futebol, acreditamos, sobretudo à espera do instante mágico em que o que parecia decidido se altera e a paisagem do possível parece reconfigurar-se. 0 futebol nunca é tão arrebatador quanto no momento em que a equipe irremediavelmente dominada começa subitamente a se impor ou, após evitar o gol adversário durante toda uma partida, marca no lance final o tento decisivo que lhe garante a vitória ou o título. Por isso é familiar, aos muitos milhões de torcedores-espectadores que encontram tempo para exercer essa dupla cidadania, a sensação simultânea de calma e fascínio advinda de assistir a jogos memoráveis em que o time para o qual se torce não está envolvido.

Torcedor e espectador são funções distintas e discerníveis, mas que costumam andar juntas na experiência do futebol. 0 torcedor aprende com o jogo a administrar a dor das derrotas e a glória dos triunfos; o espectador, sempre à espera de beleza e mudança, se regozija com as surpresas que o futebol nunca deixa de proporcionar. Ambos experimentam no cotidiano dos torneios algumas dicotomias que são dramatizadas de forma lúdica e engenhosa no futebol: competência e sorte, perseverança e aceitação, entrega e distanciamento, vontade e acaso, vitória e derrota, justiça e caos.

\section{TORCER POR UM TIME}

José Miguel Wisnik descreve seu processo de escolha de time, dividido entre as alternativas que lhe ofereciam os diversos clubes da São Paulo de sua infância, como a eleição arbitrária "de um objeto para ideal-de-eu, com a consequente inclusão forçosa num campo de compartilhamento, no qual passamos a acreditar e ao qual passamos a pertencer como se essa identificação nunca tivesse sido objeto de uma escolha arbitrária". ${ }^{26}$ Que ele, assim como Nuno Ramos, tenha optado pelo Santos de Pelé, o fenômeno futebolístico mais marcante da época e provavelmente da história do futebol de clubes no Brasil, apenas sublinha um certo sentido de aleatoriedade e

\footnotetext{
${ }^{26}$ WISNIK. Veneno remédio, p. 34.
} 
de contingência histórica que suas palavras sobre a escolha do clube, apresentada por ele como a primeira decisão grande e definitiva a ser tomada na vida, traçam com precisão:

Para a criança já capturada pelo fascínio do futebol, talvez seja a primeira decisão pressentida como sendo um ato que alterará a sua vida inteira. Um rito de passagem oficiado no recesso de um foro íntimo imenso e quase virgem. (...) Não acho que esteja exagerando: a escolha do time de futebol redobra, por um gesto nosso, a sujeição primeira a um nome, a inclusão na ordem da linguagem e a identificação inconsciente com um objeto de amor. Ou seja, reencena as bases do nosso processo de identificação, dando-lhe um fanático teatro em que se desenvolver e se esquecer. Alimentado e açulado pelas motivações grupais e sociais, não é à toa que passamos a defendê-lo pela vida inteira, às vezes furiosa e desesperadamente. ${ }^{27}$

Podemos escolher por imitação de um modelo, tipicamente o time do pai, ou por contra-identificação, já dentro do espírito do jogo onde a existência do outro me nega e me afirma ao me negar. Os conflitos bélicos e as divisões de classe, no entanto, não são tomados ao pé da letra no futebol, onde se trata muito mais de que "o torcedor aceite a condição de que estamos sujeitos a ganhar (assumindo temporariamente uma onipotência imaginária) e a perder (recebendo uma cota de frustração e de real), ambas relativas e devolvidas ao reinício do jogo". ${ }^{28}$ A adesão aos clubes, então, "vai sendo apropriada pelas gerações ao sabor das vitórias e derrotas sazonais, decantando-se em parcelas de torcida com perfil etário sintomático, que registram a memória de épocas vitoriosas em que se deu a identificação infantil com o clube". ${ }^{29}$

Hans Ulrich Gumbrecht enfatiza que não assiste a esportes com objetivos ética ou intelectualmente edificantes, mas afirma guardar "alguma esperança de que o sentimento de comunhão que me invade quando torço para meus times e pelos heróis que admiro seja algo mais que a mera satisfação de uma fantasia infantil". ${ }^{30}$ Em oposição à ética das torcidas organizadas, cujas missões torcedoras ${ }^{31}$ envolvem a crença numa capacidade de interferir no desempenho das equipes e dessa forma influenciar o próprio real dos fatos e dos resultados, Gumbrecht se define como um torcedor para quem a fruição do esporte se fundamenta numa espécie de aceitação

\footnotetext{
27 WISNIK. Veneno remédio, p. 34.

28 WISNIK. Veneno remédio, p. 46.

${ }^{29}$ WISNIK. Veneno remédio, p. 50.

30 GUMBRECHT. Elogio da beleza atlética, p. 32.

31 HOLLANDA. O clube como vontade e representação, p. 60.
} 
do acaso. Ele fala da dimensão de concentração presente no esporte, tanto da parte dos atletas como dos espectadores, mas afirma que essa concentração parece andar sempre lado a lado com uma curiosa sensação de paz:

Estou em paz com a impressão de que não tenho como controlar e manipular o mundo que me cerca. (...) Estou aberto à próxima experiência, qualquer que ela seja. Os grandes atletas compartilham com os espectadores mais concentrados essa atitude de tranquilidade. Mas no caso dos atletas a serenidade é uma precondição para sua capacidade de fazer as coisas acontecerem (...). Não estou tentando dizer que as derrotas mais amargas dos meus times me ensinaram a absorver o golpe com a cabeça erguida. Em vez disso, sinto-me atraído para uma abertura em relação ao mundo material que me cerca, para uma abertura que faz meu arbítrio e minhas reivindicações de ação parecerem apenas marginais, vagas, quase aleatórias. ${ }^{32}$

Wisnik não está longe desse trecho de Gumbrecht quando descreve a experiência do torcedor de futebol como a de um transe, por um lado, e por outro e a de um aprendizado cujas principais lições sãs as noções de mudança e de possibilidade:

Em condições normais, a "hipnose" pelo jogo deixa o sujeito entre a realização momentânea de sua paixão, na vitória, e o convite a revisitar a sua neurose a cada derrota mais profunda. 0 que implica, no mínimo, um movimento pessoal que se movimenta e se desloca, que se vê obrigado a suportar golpes na idealização - se não for emancipador pelo tanto que contém de possível aprendizado sobre a ordem geral das coisas. (...) 0 desenho do jogo, suas variações narrativas, os instantes de beleza plástica e de inteligência, a própria rotina e o tédio convidam o espectador esclarecido a ir além da hipnose identificatória, a sair do papel restrito do torcedor clubístico ou nacionalista, e a render-se à reversibilidade e à alternância, que consistem no seu recado mais fundo. ${ }^{33}$

\section{FUTEBOL E REPRESENTAÇÃo}

Os eventos esportivos, com bastante frequência ao longo do século $\mathrm{XX}$, apareceram na crítica acadêmica como elemento constitutivo de uma cultura do entretenimento e do espetáculo que teria neles um de seus mais eficazes mecanismos de perpetuação - e não falta, ainda hoje, quem esteja disposto a reduzir os esportes de massa à produção de alienação ou a um suposto "fora sem dentro" da publicidade. Tem sido

${ }^{32}$ GUMBRECHT. Elogio da beleza atlética, p. 47.

${ }^{33}$ WISNIK. Veneno remédio, p. 53. 
também comum pensá-los do ponto de vista do conflito, ressaltando o comportamento muitas vezes agressivo dos torcedores e investigando as identidades estabelecidas entre clubes, torcidas organizadas e grupos e comportamentos sociais. Um outro tipo de análise sociológica investiga a formação dos esportes modernos em sua relação com as ideias de regra e de sagrado, buscando traçar as continuidades e descontinuidades entre rituais primitivos e os formatos atuais que, em sua maioria, foram tomando forma desde a Idade Média e ganharam uma cara mais ou menos definitiva na Inglaterra do século XIX.

Wisnik acusa algumas dessas abordagens de passar ao largo do conteúdo do jogo, atendo-se apenas a seus aspectos marginais, e vê o futebol como "um campo de jogo em que se confronta o vazio da vida, isto é, a necessidade premente de procurar-lhe sentido". ${ }^{34}$ Ele acredita que o futebol pode ser objeto simultâneo de paixão e desafio intelectual, exigindo para isso uma disposição que "não é muito diferente daquela que é pedida pela arte - que supõe certa dose de aceitação da violência simbólica e da gratuidade". ${ }^{35}$ Já Bernardo Borges Buarque de Hollanda, em seu estudo sobre torcidas organizadas, defende que o olhar depreciativo que a academia costuma dirigir ao torcedor de futebol provém de definições pouco precisas a respeito da função do espectador no teatro. Ele destaca que Brecht, em sua busca por um novo teatro e um novo público teatral na década de 1920, deslocou seu olhar das plateias artísticas para os eventos esportivos que proliferavam na Berlim daquela época, nos quais admirava a sintonia entre o "palco" e o comportamento da plateia, "a aliar entusiasmo e razão, paixão e lucidez, sensibilidade e raciocínio pelo esporte através de um conhecimento objetivo pormenorizado das regras do jogo, em contraste com o alheamento e indiferença dos espectadores de teatro". ${ }^{36}$

Jacques Rancière, por sua vez, acusa uma certa tradição crítica de ver o espectador teatral como um mal. 0 que ele chama de paradoxo do espectador opõe, de um lado, a evidente constatação de que não há teatro sem espectador e, de outro, uma concepção do espectador como marcado por uma dupla incapacidade: de conhecer, já que ignora o processo de produção do que assiste e a aparência encobriria

\footnotetext{
34 WISNIK. Veneno remédio, p. 45.

35 WISNIK. Veneno remédio, p. 46.

${ }^{36}$ HOLLANDA. O clube como vontade e representação, p. 81.
} 
a realidade do espetáculo; e de agir, já que sua condição o obriga a ficar imóvel frente ao desenrolar da performance. Conhecer e agir, em suma, aparecem como ações opostas à passividade do olhar. 0 teatro, então, seria ou uma coisa má, um palco de ilusão e passividade como quis Platão, ou então seria necessário inventar um teatro sem espectadores, onde aquele que assiste fosse sobretudo o aprendiz de alguma coisa. No lugar do voyeur passivo se faria necessário um participante ativo - seria preciso arrancar o espectador de sua passividade e fazê-lo participar do espetáculo. Não parece despropositado, embora Brecht visse o torcedor esportivo como modelo de participação, enxergar continuidade entre essa concepção do espectador teatral como um ser passivo e a tradição sociológica que vê no espectador esportivo o protótipo do homem alienado da sociedade do espetáculo.

Para Rancière, que certamente não vê no público esportivo as virtudes e a saída possível que Brecht via na década de 1920, Brecht e Artaud representariam duas correntes reformadoras do teatro segundo as quais o espectador deveria ganhar a distância de um detetive que chega a conclusões, no caso de Brecht, ou perder toda a distância e ser tragado para dentro do espetáculo, como quis Artaud. Ambas as lógicas apresentam em comum, segundo Rancière, uma tendência do teatro a suprimir-se a si mesmo para se realizar. Indagação distante e participação vital, para o autor, traçam caminhos opostos, mas que responderiam, ambos, a uma tentativa de reforma do teatro apoiada em equivalências e oposições que precisam ser revistas. Os reformadores do teatro se assemelham, para Rancière, aos pedagogos que veem na educação a tarefa de suprimir a distância entre o saber do mestre e a ignorância do ignorante, sem perceber que a tentativa de redução do abismo só é capaz, no fundo, de recriá-lo a cada passo.

A essa pedagogia, que chama de embrutecedora, Rancière opõe a prática da emancipação intelectual, que assume a igualdade das inteligências como pressuposto. 0 mestre ignorante, curioso personagem que aparece em oposição à lógica embrutecedora, figura como aquele que abriu mão do saber relativo à ignorância e, dessa forma, é capaz de dissociar o ensino que pratica do saber que possui - o que ele ignora é, justamente, a desigualdade das inteligências. Por isso a relação entre aluno e professor pede sempre um terceiro elemento, normalmente o livro, que seja estranho a ambos. A ele o mestre ignorante e o aprendiz emancipado podem sempre 
recorrer de forma a comparar signos, imagens e significados. No caso do teatro esse papel mediador é desempenhado pela própria performance teatral, que não é a transmissão do saber do artista para o espectador, mas antes essa terceira coisa de que nenhum dos dois é proprietário e que, sem sentido prévio, se dá para além de qualquer relação possível de causa e efeito. 0 espectador participa da performance refazendo-a sempre à sua maneira, imprimindo nela os seus próprios significados através de aberturas, recusas e associações:

É neste poder de associar e de dissociar que reside a emancipação do espectador, ou seja, a emancipação de cada um de nós enquanto espectador. Ser espectador não é a condição passiva que devêssemos transformar em actividade. É a nossa situação normal. Aprendemos e ensinamos, agimos e conhecemos também enquanto espectadores que ligam constantemente 0 que vêem com aquilo que já viram e disseram, fizeram e sonharam. ${ }^{37}$

O que se proporá aqui, à guisa de conclusão, é que os eventos esportivos, e em especial os futebolísticos por sua abertura constitutiva ao acaso, são exemplos populares dessas narrativas que se dão aos espectadores para as mais diversas apreciações e apropriações. 0 futebol, assim como o teatro e o cinema, enreda atores e espectadores em uma dramatização que relativiza, desestabiliza e deixa ver algo do mundo. 0 "e se" de Nuno Ramos, com suas bifurcações e virtualidades, no fim das contas é o mesmo das ficções que acompanhamos em livros, cinemas e salas de teatro. A diferença, se houver, não residirá em uma suposta qualidade estética que estaria presente nas artes e ausente do futebol, mas no fato de o futebol, que diferentemente do teatro ou do cinema não remete em última instância à mente supostamente controladora de um diretor, não estar nem mesmo sob a suspeita de antecipar seus efeitos em função de um cálculo de recepção.

0 jogo de futebol é um terceiro elemento, tal qual a obra de arte, a peça de teatro ou o livro que liga o mestre ignorante ao aluno. Mas um terceiro elemento que media a relação de centenas de milhões de seres humanos com o próprio jogo do mundo.

${ }^{37}$ RANCIÈRE. O espectador emancipado, p. 28. 


\section{REFERÊNCIAS}

CAILLOIS, Roger. Os jogos e os homens: a máscara e a vertigem. Lisboa: Cotovia, 1990.

DaMATTA, Roberto e outros. Universo do futebol: esporte e sociedade brasileira. Rio de Janeiro: Pinakotheke, 1982.

FINK, Eugen. Le jeu comme symbole du monde. Paris: Les Éditions de Minuit, 1966.

GUMBRECHT, Hans Ulrich. Elogio da beleza atlética. São Paulo: Companhia das Letras, 2007.

HOLLANDA, Bernardo Borges Buarque de. O clube como vontade e representação: o jornalismo esportivo e a formação das torcidas organizadas de futebol no Rio de Janeiro. Rio de Janeiro: 7Letras, 2009.

HUIZINGA, Johan. Homo ludens: o jogo como elemento da cultura. São Paulo: Perspectiva, 2010.

MICHÉA, Jean-Claude. Le plus beau but était une passe: écrits sur le football. Climats, 2018.

RAMOS, Nuno. Ensaio geral: projetos, roteiros, ensaios, memória. São Paulo: Globo, 2007.

RANCIÈRE, Jacques. O espectador emancipado. Lisboa: Orfeu Negro, 2010

TOSTÃO. A perfeição não existe: crônicas de futebol. São Paulo: Três Estrelas, 2012. WISNIK, José Miguel. Veneno remédio: o futebol e o Brasil. São Paulo: Companhia das Letras, 2008.

Recebido para publicação em: 15 fev. 2021.

Aprovado em: 25 ago. 2021. 